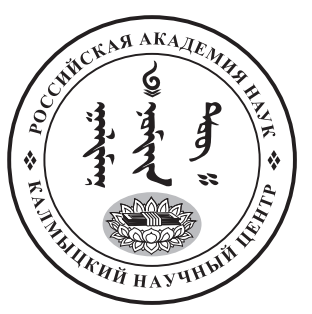

Published in the Russian Federation

Oriental Studies (Previous Name: Bulletin of the Kalmyk Institute

for Humanities of the Russian Academy of Sciences)

Has been issued as a journal since 2008

ISSN: 2619-0990; E-ISSN: 2619-1008

Vol. 14, Is. 4, pp. 658-672, 2021

Journal homepage: https://kigiran.elpub.ru

УДК / UDC 94(575.4)

DOI: $10.22162 / 2619-0990-2021-56-4-658-672$

\title{
Туркмены в контексте региональной внешней политики в Центральной Азии первой половины XIX в.
}

\author{
Сергей Дмитриевич Васильев ${ }^{1}$
}

${ }^{1}$ Московский городской педагогический институт (4, 2-й Сельскохозяйственный проезд, 129226, Москва, Российская Федерация)

аспирант

iD 0000-0001-6126-8981. E-mail: visaramis@mail.ru

\author{
(C) КалмНЦ РАН, 2021 \\ (С) Васильев С. Д., 2021
}

Аннотация. Введение. В предлагаемой статье рассматривается роль Персии, Российской империи, Великобритании и Хивинского ханства в политических отношениях вокруг туркмен на западе Центрально-Азиатского региона. Особое место отведено анализу динамики урегулирования российско-персидских отношений по вопросу о туркменских владениях в первой половине XIX в. Фактически туркмены не имели централизованной системы управления и представляли собой множество родственных и противоборствующих племен, каждое из которых стремилось сохранить свой традиционный уклад жизни. Согласованные действия туркмен прослеживаются лишь в периоды персидской агрессии. Поэтому цель настоящей статьи состоит в рассмотрении истории туркмен указанного периода в контексте борьбы за сохранение независимости от региональных и мировых держав. Материаль и методы. Аналитика статьи основывается на многоплановой ираноязычной, русскоязычной и англоязычной источниковой базе, характеризующей дипломатические отношения в регионе и роль в них туркменских племен. Эти источники анализируются в статье с позиции выявления роли туркмен в российско-иранских отношениях, что делается в современной исторической науке впервые. Заявленные источники обусловили использование следующих исследовательских методов: критика и анализ письменных источников, анализ явлений и синтез полученных результатов, индукцию и дедукцию, которые дают возможность сформировать общее представление о международных отношениях в Закаспийском субрегионе Центральной Азии и исследовать роль и место туркмен в региональной геополитике. Специфика работы заключается в том, что туркмены рассматриваются не столько как этнокультурный феномен, сколько как объект одного из эпизодов Большой игры на Востоке. При этом нельзя утверждать, что туркмены не пытались повлиять на ход геополитики в регионе. Результаты. Оказывая активное сопротивление своим традиционным врагам — персам и хивинцам — и лавируя между ведущими державами в ходе борьбы за свою независимость, туркменские роды становились участниками Большой игры в Центральной Азии. 
Ключевые слова: Российская империя, Иран, Центральная Азия, туркмены, военно-географические экспедиции, дипломатия, геополитика, XIX век

Благодарность. Исследование выполнено за счет гранта Российского научного фонда «Центральная Азия в международных отношениях XVIII-XIX в.» (проект № 19-18-00162), реализуемого в Институте языков и культур имени Льва Толстого.

Для цитирования: Васильев С. Д. Туркмены в контексте российско-иранских отношений первой половины XIX в. // Oriental Studies. 2021. Т. 14. № 4. С. 658-672. DOI: 10.22162/26190990-2021-56-4-658-672

\title{
Turkmens in Russia's Foreign Policy in Central Asia, Early to Mid 19 Century
}

\author{
Sergey D. Vasilyev ${ }^{1}$ \\ ${ }^{1}$ Moscow City University (4, Vtoroy Selskokhozyaistvennyi Proezd, 129226 Moscow, Russian \\ Federation) \\ Postgraduate Student
}

(iD)0000-0001-6126-8981.E-mail: visaramis@mail.ru

(C) KalmSC RAS, 2021

(C) Vasilyev S. D., 2021

\begin{abstract}
Introduction. The article examines the politics of Persia, the Russian Empire, Great Britain, and the Khiva Khanate in their relations with Turkmens in the west of the Central Asian region, with special attention given to the dynamics of Russian and Persian interaction on the issue of Turkmen's territories in the first half of the $19^{\text {th }} \mathrm{c}$. At the time, Turkmens, lacking any central organization, were a multitude of related and opposing clans, each of which strove to preserve its traditional way of life; their actions were concerted only during the periods of Persian aggression. The present article aims at studying the Turkmens' history of the period in the context of their struggle for independence against regional and world powers. Materials and methods. The research is based on a great variety of Iranian, Russian, and English sources, shedding light on their diplomatic activities in the region and the role of Turkmen clans. Thus, the material is examined, with a focus on the role of Turkmens in Russian and Iranian relations; this innovative approach is intended to fill in the existing gap in the research. Several methods employed in the study were as follows: criticism and analysis of written sources, analysis of phenomena and summing up of the results obtained, induction and deduction; these facilitated an understanding of the general international context in the Transcaspian subregion of Central Asia and of the Turkmens' part in the regional geopolitics. Notably, Turkmens are not viewed purely in ethnocultural terms, but rather as an object and subject of the Great Game in the East because, undoubtedly, they took efforts to influence the course of geopolitics in the region. Conclusion. Actively resisting their traditional enemies - Persians and Khivans - and maneuvering between the leading powers in the struggle for their independence, the Turkmen clans became participants in the Great Game in Central Asia.

Keywords: Russian Empire, Iran, Central Asia, Turkmens, military-geographical expeditions, diplomacy, geopolitics, $19^{\text {th }}$ century

Acknowledgements. The reported study was granted by Russian Science Foundation, project no. 19-18-00162 'Central Asia and International Relations, $18^{\text {th }}-19^{\text {th }}$ Centuries' implemented at the Leo Tolstoy Institute of Languages and Cultures.

For citation: Vasilyev S. D. Turkmens in the Context of Russia's Foreign Policy in Central Asia, Early to Mid $19^{\text {th }}$ Century. Oriental Studies. 2021. Vol. 14 (4): 658-672. (In Russ.). DOI: 10.22162/26190990-2021-56-4-658-672
\end{abstract}




\section{Введение}

В предлагаемой статье история туркмен XIX в. рассматривается на фоне развития внешнеполитической ситуации на западе Центрально-Азиатского региона. Разобщенные туркменские племена воспринимаются в большей степени фоном, на котором развиваются державные амбиции и внешнеполитические интересы соседних государств - России, Ирана, Хивы и Британии (через Ост-Индию и активную позицию империи на Среднем Востоке).

Надо признать, что согласованные действия туркмен прослеживаются лишь в периоды персидской агрессии, и сегодня нет достаточных оснований утверждать, что они пытались повлиять на развитие геополитической ситуации в регионе. Тем не менее, оказывая активное сопротивление своим традиционным врагам - иранцам и хивинцам, лавируя между ведущими державами в ходе борьбы за свою независимость, туркменские роды становились участниками Большой игры в Центральной Азии.

Актуальность исследования определяется значимостью понимания роли туркмен в региональных международных отношениях, необходимостью конкретного объяснения обращений туркменских старшин с просьбами о российском подданстве утилитарными соображениями. Кроме того, анализ событий, происходивших на Среднем Востоке в указанный период, дает богатый материал для характеристики методов и приемов урегулирования пограничных и межэтнических конфликтов.

В статье рассматривается место туркмен в политике держав, активно оперировавших в Центральной Азии первой половины XIX в. Выяснение мер российской администрации, предпринимавшихся в отношении туркмен в рамках реализации имперского геополитического курса в Центральной Азии, способствует пониманию современных актуальных политико-стратегических вопросов и дает возможность указать на варианты их решения.

Новизна предлагаемого подхода к изучению истории туркмен состоит в стремлении расширить спектр акторов внешнепо- литических отношений, в которых участвовали туркменские племена и роды, показать международные отношения вокруг туркмен как один из важных актов Большой игры на Востоке.

\section{Материалы и методы}

В статье применяются исторический и логический методы, дедукция и индукция, системный анализ и др.

Использование логического метода дает возможность рассмотреть суть и содержание международных отношений в регионе, а исторического - позволяет увидеть трансформацию региональной геополитики во времени.

Системный подход позволяет рассмотреть геополитическую реальность как систему - результат взаимосвязи и взаимодействия отдельных ее субъектов, что формирует в итоге новые качества системы, отсутствующие у ее элементов. Этот подход дает возможность увидеть в региональной внешней политике единую систему, подверженную периодическим трансформациям и представленную экономической, социальной, военно-политической подсистемами.

Источниками для настоящей статьи послужили письменные документы XIX в. и более раннего времени, которые характеризуют положение туркменских племен в Новое время и накануне принятия ими российского подданства [МИТТ 1938; ПТР 1960; PTO 1963].

В настоящей статье цитируются извлечения из «Истории Средней Азии» Мир Абуль-Керима бухарского в переводе Г. А. Мирзоева, «На̄сих-ат-тава̄рих» («Тарих-и-Каджа̄рийе»), сочинения Мирза Мухаммад Таги Сепехра, перевод Н. Дьяконовой; «Тарих-и-мунтазам-и-Насири», сочинения Мухаммад Хасан-хана, перевод К. Н. Фрейтага; «Матла-уш-шамс», сочинения Мухаммад Хасан-хана, перевод под ред. А. А. Ромаскевича; «Ма'асир-и-султа̄нийе», сочинения Абд-ур-Раззака, перевод под ред. А. А. Ромаскевича; «Сафа̄рат-на̄ме-иХа̄разм», сочинения Риза-кули-хана, перевод А. А. Ромаскевича; «Рузна̄ме-йи-Хакимуль-Малик», дневника шаха Насир-уд-дина, перевод под ред. А. А. Ромаскевича [МИТТ 1938: 194-323] 
В них отражена история взаимодействия туркмен с Хивинским ханством: участие в хивинских походах и столкновениях двух сторон, отношения с хивинской администрацией. Среди этих документов есть материалы, отражающие роль туркмен в хивинско-иранских отношениях. Например, извлечение из «Надир-намэ» или «Китаб-и-Надири» - сочинения Мухаммед Казима в переводе П. П. Иванова [МИТТ 1938: 186-187].

Персидские источники сохранили информацию о туркменских волнениях, целью которых было освобождение от персидской власти [Сепехр 1390 (2011/2012)1: 703-704, 767-768]. Иранские происки в направлениях на Мерв и Герат получили отображение в истории царствования Алла-Кули-хана, зафиксированной в извлечении из «Рияз-уд-довле» сочинения Мухаммед Резы Мираба Агехи в переводе А. К. Боровкова [МИТТ 1938: 427-476].

C начала XIX в. активизируется интерес к туркменам со стороны российского правительства, и они оказываются в центре дипломатических и военно-стратегических планов Санкт-Петербурга. Возникают документальные комплексы, отражающие неоднократные попытки туркмен принять российское подданство, историю первых российских исследований региона, дискуссии о целях и направлениях проникновения в Туркменскую степь и т. п. Огромный комплекс документов этого рода был опубликован в Ашхабаде в 1963 г. [РТО 1963].

Стремление отдельных групп туркмен под российский скипетр нашло отражение в материалах Астраханской почтовой таможни, документах оренбургского губернского начальства, туркменских прошениях [РТО 1963: 134-138, 260].

Особого внимания заслуживает переписка российских консулов в Иране и российского дипломатического ведомства, характеризующая настроения внутри туркменских племен и намерения царского правительства [РТО 1963: 165-169].

Просьбы туркмен не всегда оставались без внимания: свидетельства об этом отложились, например в делопроизводстве кавказской администрации [РТО 1963: $191-$

1 Указан год издания по солнечной хиджре; по григорианскому стилю — 2011/2012 г.
192]. Там же сформировался документальный комплекс, связанный с российскими экспедициями на восточный берег Каспийского моря [РТО 1963: 205]. С кавказскими властями связаны и документы, касающиеся чрезвычайно важной для развития российско-туркменских отношений экспедиции Г. С. Карелина на юго-восточный берег Каспия [РТО 1963: 271, 300-306, 308-317].

Другое направление российского проникновения в Туркменскую степь - Мангышлак - отражено в военной переписке середины XIX столетия [РТО 1963: 396400] и в материалах, связанных с экспедицией полковника В. Д. Дандевиля [РТО 1963: 465-470, 479-482, 484-489].

Дипломатические соглашения России и Ирана, заложившие основу отношений двух стран, а также к туркменам, опубликованные еще в позапрошлом столетии [Юзефович 1869], стали источниками данного исследования.

Представленные исторические источники анализируются в статье в свете роли туркмен в российско-иранских отношениях, что осуществляется впервые в современной исторической науке.

Привлечение заявленных источников обусловило использование в статье таких методов исследования, как критика и анализ письменных источников, анализ явлений и синтез полученных результатов, индукцию и дедукцию, которые дают возможность сформировать общее представление о международных отношениях в Закаспийском субрегионе Центральной Азии и исследовать роль и место туркмен в региональной геополитике.

Туркмены в региональной политике первой половины XIX в.

\section{Историография}

В современной исторической науке центральноазиатский треугольник Россия-Иран-Великобритания уже становился центром научных исследований [Васильев 2019; Васильев, Васильев 2017б], равно как и история двухсторонних российско-британских отношений на Среднем Востоке [Васильев, Васильев 2017а]. Однако поднятая проблематика требует уделить большее внимание отдельным аспектам региональных отношений.

Анализ военно-политических событий и взаимоотношений Хорезма и Ирана в пер- 
вой половине XVIII в. предложен в работе Д. А. Ализоды. Автор раскрывает причины и порядок военных походов Надир-шаха Афшара в Хорезм, отмечает сопротивление туркмен иранским войскам [Ализода 2018].

Участию северных туркмен во внешнеполитическом противостоянии Хивы и Ирана посвящена диссертация С. Д. Атдаева [Атдаев 1993]. Внешнеполитический аспект жизни туркмен рассмотрен А. Т. Атаевым [Атаев 2017]. Вопросы транзитной торговли затронуты в диссертации М. М. Имашевой [Имашева 2004]. Правовые аспекты межгосударственных отношений в регионе являются предметом исследований известного российского правоведа $\mathrm{P}$. Ю. Почекаева [Почекаев 2019а; Почекаев 2019б; Почекаев 2016].

Современный исследователь Ш. Х. Кадыров в истории туркмен акцентирует внимание на борьбе и взаимодействии отдельных этнических групп [Кадыров 2003].

А. Р. Ихсанов анализирует внутритуркменские взаимоотношения в первой половине XIX в. на примере теке и йомудов [Ихсанов 2014]. О. В. Попкова, говоря о военной активности туркмен, обращает внимание не только на их национальное, но также государственно-политическое самосознание [Попкова 2016].

Наиболее близки к проблематике статьи диссертационные исследования Д. Б. Салиховой [Салихова 2007] и О. А. Никонова [Никонов 2011], а также работа последнего, посвященная российской политике в отношении туркмен в первой половине XIX в. [Никонов 2009], и работа И. И. Аминова [Аминов 2017].

Экономическая политика российского правительства на туркменском побережье Каспия рассмотрена в работе Э. М. Оздамировой [Оздамирова 2015].

Однако намерение рассмотреть туркмен в качестве субъекта региональных отношений требует более пристального внимания к оценке (переоценке) их роли в региональной политике. Первые шаги российской администрации по закреплению в Закаспийском крае в конце 1860-х - начале 1870-х гг. достаточно подробно освещены Д. В. Васильевым [Васильев 2020]. В настоящей статье будет рассмотрен предшествующий период.

\section{Туркмены и Хива}

Конец XVIII - начало XIX в. в истории туркмен можно охарактеризовать как период восстановления от продолжительного и жестокого давления персидского правительства в лице основателя династии Афшаридов Надир-шаха Афшара (1736-1747). Территориально разобщенные и изнуренные разрушительными персидскими экспедициями, туркмены все чаще изъявляли желание объединить свои усилия в борьбе с традиционными врагами - Хивой и Персией.

На время освободившись от персидского давления, теперь туркмены старались избежать насаждения власти хивинских ханов. Естественно, такие стремления не устраивали хивинских и персидских правителей. Им необходимо было вновь установить контроль над туркменами - привычными поставщиками качественного скота, первоклассных лошадей и рабочей силы.

В результате образования Хивинского ханства в 1512 г. местным немногочисленным племенам туркмен-йомудов пришлось признать пришлую узбекскую власть. Они платили дань ханам Хивы и принимали участие в их походах на соседние государства [МИТТ 1938: 223-236].

Однако в XIX в. отношения туркмен с ханом начали ухудшаться. Такое сотрудничество было выгодно лишь хивинским властям. Туркмены теряли сотни людей в столкновениях с Хивой. Поэтому они все чаще стали игнорировать предложения хивинских ханов об участии в походах на соседние страны. Последовала незамедлительная реакция правителя Хивы, который развернул серию кампаний, целью которых стало установление контроля над туркменами [МИТТ 1938: 353-354, 355-370].

В 1804 г. хивинский хан Эльтузер направил свои войска на йомудов в Астрабад и Горган. Здешние туркмены оказывали активное сопротивление хивинским властям. В результате похода было убито 500 туркмен, столько же человек взято в плен [МИТТ 1938: 202-203].

Не успевшим оправиться от хивинской атаки туркменам предстояло вновь столкнуться с угрозой. На этот раз агрессором выступила персидская династия Каджаров (1785-1925). 
Туркмены между Ираном и Россией в начале XIX в.

Каджары пришли к власти в Персии в конце XVIII в. и были не менее агрессивно настроены против туркмен, чем Надир-шах и афшариды. Однако центральное место во внешнеполитическом курсе нового персидского правительства занимал конфликт с русскими. Потери на Кавказе, особенно в Грузии, вызывали беспокойство у персидских властей [Sykes 1921: 388-391]. Нужны были успешные действия на внешнеполитической арене. По этой причине каджарское правительство начало готовить серию кампаний в Туркмению.

Внимание российских властей к туркменам Закаспийского края возрастало по мере ухудшения отношений с Персией, владетели которой постоянно осуществляли военные экспедиции против туркменских племен. В итоге пограничные туркмены всегда были настроены антиперсидски [Иванов 1983: 51].

Очевидно, туркмены готовились к неминуемой агрессии со стороны каджарского правительства. Еще в 1801 г. два туркменских лидера из племени човдуров обратились к русским за протекцией. Причиной обращения стали частые конфликты с хивинским ханом [РТО 1963: 133-138].

Спустя несколько лет просьбы туркмен о протекции возобновились. Они намеревались получить от России поддержку на случай войны с Персией. Соответствующая переписка велась с йомудами, гокланами и текинцами в мае - сентябре 1805 г. [Лобысевич 1900: 61].

Имперский консул в Персии М. Д. Скибиневский докладывал в Петербург, что туркмены сами выразили желание начать войну против персидских властей [РТО 1963: 165].

Российское правительство собиралось направить к туркменам муллу Мамед-Джан-Хусейна, на которого планировалось возложить их подготовку к наступлению против войск Фатх-Али-шаха [РТО 1963: 166-169]. Однако из-за разгоревшейся войны с персами проекты помощи туркменам пришлось отложить.

Присоединение к империи Восточного Кавказа повлекло за собой образование Грузинской губернии из земель Картли-Кахетинского ханства, а присоединение к Рос- сии Менгрелии в 1803 г. расширило границы государства вплоть до пределов нынешнего Азербайджана. В итоге разгорелась война, завершившаяся Гюлистанским миром [Юзефович 1869: 208-214], который признал за Россией Карабахское, Ганджинское, Шекинское, Ширванское, Дербентское, Кубинское, Бакинское и Талышское ханства, Дагестан, Грузию, Имеретию, Гурию, Мингрелию и Абхазию [Иванов 1952: 117].

Четвертая статья Гюлистанского договора возлагала на Россию обязанность признавать того наследника престола, который будет назначен персидской стороной [Кузнецова 1983: 5].

Пятая статья признавала за Российской империей исключительное право на военный флот в Каспийском море, а, согласно девятой статье, таможенные пошлины для российских купцов не могли превышать $5 \%$, установленных персами для единоверцев. Кстати, российское правительство предъявляло то же коммерческое требование к Бухаре, Коканду и Хиве позднее, в период глубокого освоения империей Центральной Азии.

Во время русско-персидской войны (1804-1813) каджарское правительство все же нанесло серию ударов по туркменам. В 1809 г. персидская армия под руководством Мохаммед-Вели-Мирзы атаковала туркменский г. Нису. Персы убили множество туркмен и захватили 100000 голов скота [Росляков 1955: 41-42]. Четыре года спустя, в 1813 г., персидская армия под предводительством каджарского принца Мохаммед-Кули-Мирзы (Мохаммед-шаха) нанесла неожиданный удар по туркменам г. Бами [Saray 1989: 67]. Персы выбрали время, когда туркмены праздновали национальный религиозный праздник.

Через полгода, осенью 1813 г., хивинский хан Мухаммад Рахим направил экспедицию в Хорасан для завоевания персов и призвал текинцев и гокланов присоединиться к походу [МИТТ 1938: 186-187].

Туркмены, только что пережившие серию персидских атак, ответили отказом. Прибыв в Хорасан, Мухаммад Рахим не решился идти на персов без помощи туркмен. Вынужденный свернуть кампанию, он был разозлен отказом туркмен и на обратном пути напал на несостоявшихся соратников [МИТТ 1938: 186]. 
Положение туркмен оставляло желать лучшего. Измученные непрерывной агрессией персов и хивинцев, они вновь обратились за помощью к русским. В 1811 г. с просьбой о переходе в российское подданство обратились човдуры, вышедшие к этому времени из Хивы с намерением переселиться в Россию. Это прошение в ноябре следующего года в Астрахани повторила човдурская делегация, которой пришлось довольствоваться приобретением 5000 четвертей хлеба [РТО 1963: 184].

Накануне заключения Гюлистанского мира в 1813 г. прибрежные туркмены подняли антиперсидское восстание [Сепехр 1390 (2011/2012): 703-704, 767-768]. В труде Мухаммада Таги Сепехра есть рассказ о восстании: «Кият ${ }^{2}$ из туркменской семьи джафарбай оккупировал остров Чаркен ${ }^{3}-$ ценный источник нефти и соли. Этот остров имеет диаметр в 6 фарсангов, расположен в Каспийском море напротив Баку... Кият организовал монополию на берегу Каспийского моря на торговлю солью и нефтью, а туркменские общины начали стягиваться к нему...» [Сепехр 1390 (2011/2012): 703-704].

Принц Ардашир-Мирза смог покончить с восстанием лишь в 1826 г. Восставшие пытались опереться на российскую военную мощь и обратились с соответствующей просьбой. Петербург принципиально был готов оказать поддержку морским десантом, артиллерией, другими военными поставками [РТО 1963: 191-192].

Однако в это время посланники Фатх Али-шаха заявили о готовности заключить с Россией мир. Случилось все это в местечке Гюлистан на территории Карабаха. Следует признать, что обращение повстанцев стало разменной картой в борьбе за выгодные для империи условия. Одержав дипломатическую победу, российская сторона была вынуждена отказать туркменам.

Присоединение Грузии и Азербайджана символизировало окончательное и устойчивое утверждение Российской империи на западе каспийского побережья. Отсюда открывалось теперь новое направление для связи с туркменскими землями. Гюлистанский договор положил начало последовательному упрочению позиций России на юго-восточ-

\footnotetext{
${ }^{2}$ Он же Кият-хан, Кият-ага, Кият бек.

3 Челекен.

4 Здесь и далее перевод автора статьи.
}

ном побережье Каспийского моря.

Туркмены в условиях роста российского влияния в Каспийском регионе

Установление российского господства в Каспийском регионе взбудоражило Великобританию, которая имела торговые интересы в регионе. В 1814 г. британские власти заключили союз с персами для того, чтобы упрочить свое торговое и политическое положение в этом регионе [Rawlinson 1875: 35-37]. Соглашение подразумевало оказание материальной помощи персам и утверждало политическую значимость британских властей в качестве посредника в российско-персидских отношениях.

В это время генерал А. П. Ермолов, командующий российскими военными силами на Кавказе, решил воспользоваться сложившейся благоприятной ситуацией в Каспийском море и развернул активную торговлю с Хивой, Бухарой и закаспийскими туркменами. В 1819 г. А. П. Ермолов отправил двух своих офицеров - майора М. И. Пономарева и капитана Н. Н. Муравьева для установления дружественных отношений с туркменами [РТО 1963: 205]. М. И. Пономарев был отправлен на восточный берег Каспия. Н. Н. Муравьев направился в Хиву для сбора информации о туркменах и хивинцах, но главной его целью все же было установление союза с хивинским ханом.

После получения воодушевляющих отчетов от своих подопечных А. П. Ермолов в 1820 г. направил письмо российскому правительству, в котором сообщал, что в такой подходящий момент России следовало бы основать торговый форпост в Мангышлаке, что гарантировало бы русские торговые интересы на пути из Астрахани в Хиву и обеспечивало бы безопасную торговлю русским купцам и рыбакам на восточном берегу Каспийского моря. Российское правительство в Санкт-Петербурге одобрило предложение А. П. Ермолова.

Действия русских в Центральной Азии вызывали беспокойство в Лондоне. Британские власти получали сообщения о распространении русского влияния среди туркмен на восточных берегах Каспия. Поступательное движение русских в Центральной Азии в Великобритании воспринимали как угрозу Британской Ост-Индии.

Английские дипломаты в Тегеране и Санкт-Петербурге не смогли успешно вы- 
ступить в роли посредников в русско-персидских отношениях [Saray 1989: 66]. Причиной тому стало крайнее разочарование персидских властей по поводу потери своих владений и острое желание вернуть их.

Поддерживая мирное направление российско-персидских отношений, новый российский император не хотел верить сообщениям о концентрации иранских военных подразделений у границы и не реагировал на предложения А. П. Ермолова об усилении кавказской группировки. Вместо этого в иранскую столицу выехало посольство наделенного особыми полномочиями князя А. С. Меньшикова. Англичане отреагировали на это активизацией антироссийской пропаганды. Они представляли шаху российское посольство как проявление слабости.

Практически одновременно с российской миссией на месте переговоров в Солтание оказался проповедник моджтехид Кербелайский, обнародовавший фетву с призывом к священной войне против русских. Миссия потерпела фиаско, а в условиях начавшейся войны российские дипломаты превратились в пленных. Начавшиеся военные действия стимулировали прежних правителей этих территорий к организации мятежей [Ракович 1900: 62-63].

Однако военные действия развивались в пользу России. И вновь с 9 на 10 февраля 1828 г. в местечке Туркманчай был заключен новый мирный договор, дававший империи больше преимуществ на территории Ирана и ущемлявший в некоторой степени британские интересы [Пашуто 1947: $127-$ 128].

Россия получила Ереван и Нахичевань и обещание выплатить 20 млн руб. серебром [Юзефович 1869: 215]. Одновременно российские купцы получили особые привилегии [Юзефович 1869: 223-225]. Каспий фактически стал внутренним российским водоемом.

Заключение Туркманчайского договора серьезно обеспокоило британские власти, которые, прежде всего, стремились защитить свои торговые интересы в регионе. Англичане посчитали, что их товары, проходившие через Табриз, смогут легко конкурировать с российскими, если персидские власти уменьшат пошлину до 5 процентов, как это было сделано для российских товаров [Saray 1989: 66].
Когда британский представитель в Тегеране Джон Кэмпбелл выступил с таким предложением, персидские власти не смогли отказать ему, так как нуждались в дружественных отношениях с Великобританией - главным противовесом растущему российскому влиянию. С политической точки зрения Британия хотела видеть сильную Персию, но не хотела помогать государству, находившемуся под влиянием русских.

В этой связи британцы решили пересмотреть свою политику в регионе и переместить фокус своего внимания на Афганистан. При этом они старались противодействовать русским в Хиве, оказывая хивинцам материальную поддержку и устанавливая дружественные контакты с местной властью. В планах британского правительства также было решение персидско-хивинских разногласий. Считалось, что для этой цели могут пригодиться туркменские племена, проживавшие на территории от Мерва до Каспия: «Они могли использоваться как связующее звено между Хивой и Персией для формирования линии обороны на восточных берегах Каспийского моря, чтобы в случае возможного продвижения русских оградить их от Индии» [Saray 1989: 67]. Bce же реальной целью британского правительства стало предотвращение движения персов на Герат. Овладеть Гератом стремились Персия, пользовавшаяся поддержкой России, и Афганистан, поддерживаемый Великобританией.

Для туркмен череда персидских поражений имела другие последствия. Йомуды, проживавшие между Астрабадом и p. Атрек, платили дань персам. Однако йомуды Каспия, занимавшиеся рыбным промыслом, не платили ничего персидским властям со времен Надир-шаха.

Туркмены в фокусе интересов России и Ирана (1830-е гг.)

После заключения Туркманчайского договора туркмены-йомуды в окрестностях Астрабада и Мазендарана начали оказывать активное сопротивление каджарскому давлению. Несмотря на это, независимость местных туркмен продлилась недолго. В 1832 г. они были вынуждены признать персидское правительство Аббаса Мирзы. Но приморские йомуды смогли сохранить свою независимость. 
Тем временем хивинские власти вновь усилили давление на туркмен Мерва. Аллакули-хан, новый правитель Хивы, успешно покорил мервских туркмен, усилив свое влияние в регионе. Он собрал дань с сарыков, текинцев и салоров, сделав их своими подданными. Спустя несколько месяцев, когда персидская армия атаковала этих же туркмен, хивинцы отказались оказать им поддержку [Sykes 1921: 324]. Такое безучастное отношение хивинских властей к положению туркмен еще больше ухудшило и без того натянутые хивино-туркменские отношения.

Осенью 1832 г., после покорения йомудов Астрабада, персидское правительство организовало поход на Серахс, чтобы расчистить путь в Герат и Мерв для своих экспедиций, запланированных в этом направлении. Большое количество салоров было убито и уведено в плен персами, которые захватили скот и имущество туркмен [МИТТ 1938: 459-463].

В то же время Российская империя продолжала расширять сферу своего влияния, исследуя восточное побережье Каспия. В 1830-х гг. русские активно развивали торговые и дружеские отношения с местными туркменами.

Российские морские экспедиции к восточному берегу Каспия начались еще в первой четверти XVIII в. и были связаны с активизацией политики Петра I в Прикаспийском регионе в целом и продолжались вплоть до 1870-х гг.

Успешному развитию торговли здесь всячески препятствовали правители Персии. Во второй половине 1820 -х гг. персидская власть оказывала значительное давление на прикаспийских туркмен в Астрабаде и Мазендеране - местах, где рыбный промысел приносил большой доход туркменским племенам.

После войны 1826-1828 гг. последовали новые просьбы туркмен о защите от персидских происков. Петербург потребовал от своего посла в Тегеране обратиться к шаху с предложением отказаться от агрессивных действий в отношении туркменских племен [РТО 1963: 260].

Одновременно империя активизировала исследовательские экспедиции в туркменские владения. В 1830 г. на юго-запад Туркмении прибыл есаул Лалаев, оставивший в своих «Записках» сведения о быте и хозяй- стве туркмен, дополненные ценной информацией о российско-туркменских отношениях [АКАК 1878: 859-861].

Экспедиции Г. Карелина, есаула Лалаева, М. Ладыженского и И. Бларамберга помогли собрать ценный материал относительно социально-политического устройства туркмен. Прежде всего, они отмечали разобщённость местного населения, которая позволяла даже отдельным родам пытаться реализовывать собственную политику, принимать персидское или хивинское подданство, а также отстаивать свою независимость. Представители имперской администрации, привыкшие взаимодействовать с казахскими ханами и султанами, единолично выступавшими от имени своих многочисленных подданных, с удивлением узнавали, что звание ханов у туркмен ничего не значит, и по тем или иным вопросам следует договариваться не то что с каждым племенем или родом, но даже с каждым отдельным аулом [Бларамберг 1978: 21; ЗИРГО 1883: 154-159; АКАК 1875: 783797].

По мере расширения знаний о кочевниках Восточного Прикаспия члены российских экспедиций в своих записках все более настойчиво проводили мысль о необходимости более решительных действий российских властей в регионе, тогда как оценка политико-правового положения туркмен становилась все более критической.

Во второй четверти XIX в., благодаря активным действиям российских исследователей на восточном побережье Каспия, сложилась наиболее благоприятная обстановка для реализации уже давно планировавшегося проекта основания торгового форпоста империи.

В 1832 г. для исследования подходящего места основания торгового форпоста к восточному побережью Каспия была отправлена экспедиция Г. С. Карелина [РТО 1963: 300-312]. Он был ознакомлен со сведениями, собранными Н. Н. Муравьевым и другими. Одной из задач экспедиции являлось и выяснение возможности установления прямого сообщения между каспийским побережьем и Хивой. Г. С. Карелину было также поручено выяснить отношение туркмен к созданию такого торгового поста. Он успешно справился с миссией и рапортовал начальству, что место Кызыл-Таш в бухте Кайдак на северо-востоке полуостро- 
ва Мангышлак является наиболее благоприятным местом для строительства крепости [PTO 1963: 271].

В 1833 г. в Санкт-Петербурге были рассмотрены вопросы, связанные с интересами России в Каспийском регионе. В июле того же года императорским указом было принято решение о создании специальной флотилии для расчистки устья реки Куры, которая несла свои воды в Каспийское море. Г. С. Карелин должен был возглавить специальную экспедицию, отвечающую за строительство форпоста в Кызыл-Таше [РТО 1963: 271]. При этом само строительство крепости не должно было выглядеть как часть планомерной российской оккупации Туркмении.

Между тем персы возобновили свою агрессию в отношении туркмен. Весной 1836 г., нанеся удар по гокланам, персы атаковали Кара-Калу - туркменскую крепость военно-стратегического значения на северной стороне р. Атрек [Saray 1989: 69]. Однако туркмены проявили особую отвагу при обороне крепости, и враги вынуждены были отступить.

Весной того же года Г. С. Карелин во главе группы купцов посетил юго-восточное побережье Каспия. Там группа туркмен-йомудов обратилась к нему с петицией [РТО 1963: 314-317]. В ней сообщалось, что здешние люди независимы от Персии и Хивы, а те оказывают сильное давление на туркмен. Последние же, в свою очередь, хотят оставаться независимыми и просят российской протекции в борьбе против хивинцев и персов. Данное прошение осталось без внимания. Вполне вероятно, что русские посчитали туркмен недостаточно искренними в своем обращении, как это уже случалось раннее.

Британцев беспокоила активная деятельность Г. С. Карелина, чье имя часто звучало применительно к коммерческим спекуляциям в Туркмении. Он всячески стремился содействовать установлению русского влияния среди туркменских племен. Лондонским правительством было принято решение направить коммерческих агентов в Туркмению, Мешхед, Герат и Балх [Хидоятов 1969: 201].

В свою очередь персидское правительство было крайне обеспокоено тем, что туркменская торговля получила активное развитие в юго-восточной части Каспийского моря. Это было связано с запретом иметь военно-морские силы в Каспийском море, наложенным на персов Туркманчайским и Гюлистанским договорами. Таким образом, туркменские купцы и рыбаки становились монополистами рыбного промысла в регионе.

Поскольку иранская экономика в результате первого гератского конфликта (1837-1841) понесла значительные убытки, персы всячески старались установить контроль на туркменами-йомудами. Каджарское правительство обращалось к русским с просьбой разрешить Персии разместить военные суда на Каспийском море, которые помогли бы установить контроль над действиями туркмен [ПТР 1960: 24-26].

Еще одна цель заключалась в ликвидации туркменских набегов, от которых страдало иранское население. На данном этапе развития событий между персидскими и российскими властями произошел интересный спор о политическом положении туркмен. Русские приняли позицию туркмен, признав, что те являются не персидскими поданными, а вполне независимым народом [Saray 1989: 71]. Поэтому персидское правительство не должно претендовать на их суверенитет, на экономический и политический контроль над ними.

Тем временем, не прислушавшись к предупреждениям капитана Александра Бёрнса, британское правительство начало кампанию в Афганистане, которая, как известно, не была успешной, а Великобритания практически утратила свои позиции не только в Афганистане.

Активизация России у восточного побережья Каспийского моря (1840-е гг.)

В 1840 г. в Астрабадском заливе по просьбе персидского правительства было учреждено постоянное русское морское крейсерство, что вполне соответствовало нормам Туркманчайского договора. Российское правительство стремилось оказать помощь своим купцам в Прикаспийском регионе, обеспечив охрану судов и перевозимых товаров. Учреждение российского морского крейсерства, с точки зрения персидского правительства, могло способствовать искоренению постоянных набегов со стороны туркмен.

Основание морской станции на АшурАде стало поворотным пунктом в истории российско-туркменских отношений. Присут- 
ствие российской власти в юго-восточной части Каспийского моря оказало непосредственное влияние на экономическую и политическую жизнь местных туркмен-йомудов.

Вскоре этот остров стал второй после Баку базой Каспийской флотилии. Среди стратегических преимуществ морской станции следует выделить наличие глубоководного фарватера, соединяющего Астрабадский залив с морем, преобладание комфортных температур и отсутствие морских волнений [Широкорад 2013: 57].

Российские купцы стали частыми посетителями юго-восточной части Каспия после заключения Туркманчайского договора и, воодушевленные присутствием морской эскадры, занимали доминирующее положение в торговой жизни региона.

Туркменские купцы и рыбаки были вынуждены получать разрешение на торговлю от российского командира и должны были посещать контрольно-пропускной пункт на Ашур-Аде до и после заключения торговых сделок. В случае, если туркмены пытались игнорировать приказы российского командования, их могли подвергнуть серьезному наказанию, а туркменского бригадира могли заключить под стражу или даже отправить в ссылку.

Важно учитывать тот факт, что русские орудия, размещенные на Ашур-Аде, могли быть использованы как против туркмен-йомудов, разворовывавших персидские территории, так и против самих персов в том случае, если они пойдут на поводу у англичан. Несмотря на вышеупомянутые регулятивные меры, туркменские племена продолжали атаки на персидские территории, а персидские власти предпринимали карательные экспедиции против прикаспийских туркмен.

Экспедиции каджарского правительства наносили существенный урон хозяйственной жизни туркмен. Однако влияние персидского правительства в районах Каспийского моря и его побережья, находившегося в пределах границ Персии, было настолько ничтожным, что не могло даже обеспечить безопасности своим гражданам от нападений туркмен.

На полуострове Мангышлак отношения между русскими и туркменами-човдурами складывались иначе. С момента возведения торгового форпоста Ново-Александровск в Кызыл-Таше в 1834 г. русская торговля не получила развития. Причиной служило то, что укрепление было основано не в самом лучшем месте. Климат был неблагоприятным, а качество воды оставляло желать лучшего. Кроме того, форпост был отдален от караванного пути, что отрицательно сказывалось на развитии русской торговли в регионе.

В 1846 г. русские срыли укрепление в Кызыл-Таше и основали новый форпост Ново-Петровск в западной части Мангышлака [РТО 1963: 396-400]. Поскольку новая крепость занимала более выгодное положение, российские власти смогли распространить свое влияние по всему Мангышлаку, населенному туркменами-човдурами.

В январе 1859 г. на специальном заседании российского правительства было принято решение рассмотреть эффективные меры с целью обезопасить интересы Российской империи в регионе. В качестве одной из таких мер предлагалось возвести еще один форпост на восточном берегу Каспийского моря. Летом 1859 г. полковник В. Д. Дандевиль отправился в экспедицию к восточному берегу Каспия.

После ряда разведывательных операций он обнаружил, что Кызыл-Су ${ }^{5}$ (Красноводск) было наилучшим местом для основания форпоста [РТО 1963: 465-470, 479-482, 484-489].

Однако, вернувшись в Оренбург, он предостерег начальство от немедленного начала строительства из-за весьма враждебных настроений туркмен. Русские на неопределенный срок прекратили всю свою деятельность на восточном побережье Каспия, чтобы убедить туркмен в том, что они не собираются оккупировать его.

К началу 1860-х гг. туркмены в результате продолжительной и ожесточенной борьбы с персами и хивинцами сумели сохранить свою независимость. В ходе противостояния продолжительному давлению персидских и хивинских властей текинцы, салоры, сарыки впервые в истории сумели объединить свои силы перед общей угрозой.

Что касается российско-иранских отношений, то в 1820-е гг. они значительно ухудшились из-за усиления в Тегеране влияния англичан. Разразившаяся по инициативе шахского правительства русско-персидская война 1826-1828 гг. завершилась подписа-

\footnotetext{
5 Тюрк. 'красная вода'.
} 
нием Туркманчайского мира, значительно укрепившего положение России в регионе и со временем открывшего перспективу конструктивного взаимодействия двух государств в Туркменской степи и на Каспии.

Важным шагом, свидетельствующим как о политической близости Российской империи и Персии, так и о готовности государств к совместным действиям по обеспечению безопасности в регионе, стало учреждение в 1840-х гг. постоянного русского морского крейсерства в Каспийском море и морской станции на острове Ашур-Аде. Причем главным объектом российской морской охраны стало противодействие пиратским и контрабандным проискам приморских туркмен.

Это взаимодействие двух государств выразилось и в том, что Персия не стала предпринимать никаких шагов против основания сначала российского форпоста в Красноводске, а затем и образования Закаспийского военного отдела и Закаспийской области. Двум государствам удалось сохранить добрососедские отношения, признав реку Атрек взаимной границей.

\section{Заключение}

История распорядилась так, что активизация туркмен во внешнеполитических отношениях в Центральной Азии выпала на XIX столетие. Несмотря на самоотверженную борьбу с иностранными захватчиками, им в различные периоды их истории приходилось признавать пришлую власть. Свободолюбивым и самоотверженным туркменским племенам зачастую не хватало организованности, централизованной власти и межплеменной коммуникации.

\section{Литература}

АКАК 1875 - Акты, собранные Кавказской археографической комиссией. Т. 6. Ч. 2. Тифлис: Тип. Главн. Управления наместника кавказского, $1875.950 \mathrm{c}$.

АКАК 1878 - Акты, собранные Кавказской археографической комиссией. Т. 7. Тифлис: Тип. Главн. Управления наместника кавказского, $1878.994 \mathrm{c}$.

Ализода 2018 - Ализода Довуд Али. О военном противоборстве Хорезма и Ирана в первой половине XVIII века (по данным письменных источников) // Вестник Таджикского государственного университета права, биз-
Предпосылки создания общенациональной идеи, равно как и административного аппарата были, но по причине географической раздробленности и отсутствия общепризнанного лидера им не суждено было реализоваться. Фактически в XIX в. туркмены представляли собой множество родственных и противостоящих друг другу племен, каждое из которых стремилось сохранить свой традиционный уклад жизни. Согласованные действия туркмен имели место лишь в случае угрозы суверенитету не отдельного племени, проживавшего на границе с соседним Туркмении государством, а всего большого сообщества в целом. И именно это создавало предпосылки для их будущей национальной консолидации.

Оказывая активное сопротивление своим традиционным врагам - персам и хивинцам, а впоследствии и новым противникам - русским, туркмены проявляли себя самоотверженными воинами, готовыми многим пожертвовать ради сохранения независимости. Именно благодаря таким качествам национального характера туркменам удалось сохранить свой народ в условиях геополитического взаимодействия мировых и региональных держав. Объективности ради следует признать, что одним из условий самосохранения в обстановке напряженности региональных политических противоречий местными старшинами виделось принятие туркменами российского подданства, неоднократные просьбы о чем поступали в Санкт-Петербург с самого начала XIX в.

неса и политики. Серия гуманитарных наук. 2018. № 1 (74). С. 40-47.

Аминов 2017 - Аминов И. И. Способы приобщения туркмен к российской государственности (XIX - нач. XX в.) // Фундаментальная наука и технологии - перспективные разработки. Мат-лы XIII Междунар. науч.-практич. конф. НИЦ «Академический». Т. 2. М.: CreateSpace, 2017. C. 169-171.

Атаев 2017 - Атаев A. T. Туркмены и внешняя политика империи Дуррани // Интернаука. 2017. № 8-1 (12). С. 27-31.

Атдаев 1993 - Атдаев С. Д. Борьба северных туркмен против господства Надир-шаха в 
Хиве: автореф. дисс. ... канд. ист. наук. Ашгабад, 1993. $20 \mathrm{c.}$

Бларамберг 1978 - Бларамберг И. Ф. Воспоминания / пер. с нем. О. И. Жигалиной и Э. Ф. Шмидта. М.: ГРВЛ, Наука, 1978. 355 с.

Васильев 2014 - Васильев Д. В. Россия и Казахская степь: административная политика и статус окраины. XVIII - первая половина XIX века. М.: Политическая энциклопедия, 2014. $471 \mathrm{c}$.

Васильев 2019 - Васильев С. Д. Британское влияние на политику шахского правительства в отношении туркменских племен. Превращение Ирана в театр политического противостояния России и Великобритании // Центральная Азия на перекрестке европейских и азиатских политических интересов: XVIII-XIX вв. М.: ОнтоПринт, 2019. C. 290-300.

Васильев 2020 - Васильев Д. В. Дуализм российской администрации на восточном берегу Каспийского моря // Вестник Санкт-Петербургского университета. История. 2020. Т. 65. Вып. 1. С. 85-107.

Васильев, Васильев 2017а - Васильев Д. В., Васильев С. Д. Британо-российское противостояние на Среднем Востоке как реакция на попытку геостратегического укрепления России в регионе в 1830-х гг. // Известия Самарского научного центра Российской академии наук. 2017. Т. 19. № 3. С. 146-151.

Васильев, Васильев 2017б - Васильев С. Д., Васильев Д. В. Иран в центре британо-российского противостояния в 1820-х гг. // Исторические, философские, политические и юридические науки, культурология и искусствоведение. Вопросы теории и практики. 2017. № 6-1 (80). С. 33-36.

ЗИРГО 1883 - Записки императорского Русского географического общества по общей географии. Т. 10. СПб.: Тип. Имп. Акад. наук, 1883. $497 \mathrm{c}$.

Иванов 1952 - Иванов М. С. Очерк истории Ирана. М.: Госполитиздат, 1952. 467 с.

Иванов 1983 - Иванов М. С. Антифеодальные восстания в Иране в середине ХІХ в. М.: Наука, 1983. 248 с.

Имашева 2004 - Имашева М. М. Торговля России со странами Востока через Астрахань в первой половине XIX века: автореф. дисс. ... канд. ист. наук. Астрахань, 2004. 16 с.

Ихсанов 2014 - Ихсанов А. Р. Взаимоотношения туркменских племен теке и йомут в XVIII-XIX вв. // Восток. Афро-Азиатские общества: история и современность. 2014. № 6. C. 32-42.
Кадыров 2003 - Кадыров Ш. Х. «Нация» племен. Этнические истоки, трансформация и перспективы государственности в Туркменистане. М.: Центр цивилизационных и региональных исследований ИА РАН, 2003. $362 \mathrm{c}$.

Кузнецова 1983 - Кузнецова Н. А. Иран в первой половине XIX в. М.: Наука, 1983. 265 с.

Лобысевич 1900 - Лобысевич Ф. И. Поступательное движение в Среднюю Азию в торговом и дипломатическо-военном отношении. СПб.: Тип. т-ва «Общественная польза», 1900. $205 \mathrm{c}$.

МИТТ 1938 - Материалы по истории туркмен и Туркмении XVI-XIX вв. T. II. Иранские, бухарские и хивинские источники. М.: Издво АН СССР, 1938. $700 \mathrm{c}$

Никонов 2009 - Никонов О. Н. Юго-восточный Каспий в политической стратегии Российской империи в первой половине XIX века // Преподаватель. XXI век. 2009. № 4. С. 214222.

Никонов 2011 - Никонов О. А. Развитие межгосударственных отношений в Азиатско-Каспийском субрегионе в XVIII-XIX вв.: автореф. дисс. ... д-ра ист. наук. М., 2011. 42 с.

Оздамирова 2015 - Оздамирова Э. М. Туркменское побережье Каспийского моря в экономической политике царского правительства в 1800-1820-е гг. // Каспийский регион: политика, экономика, культура. 2015. № 4 (45). C. 59-66.

Пашуто 1947 - Пашуто В. Т. Дипломатическая деятельность А. С. Грибоедова. Исторические записки. Т. 24. М.: Изд-во АН СССР, 1947. C. 111-159.

Попкова 2016 - Попкова О. В. Боевые действия как неотъемлемый аспект жизни кочевых туркмен в XVII - первой четверти XVIII века // Ученые записки Орловского государственного университета. 2016. № 1 (70). C. $46-49$.

Почекаев 2016 - Почекаев Р. Ю. Экономические санкции Российской империи против Хивинского ханства в XVIII и XIX вв.: причины, правовое оформление, эффективность // Вопросы правоведения. 2016. № 3 (37). C. 200-215.

Почекаев 2019а - Почекаев Р. Ю. Государство и право в Центральной Азии глазами российских и западных путешественников XVIII - начала XX в. М.: НИУ «Высшая школа экономики», 2019. 424 с.

Почекаев 20196 - Почекаев Р. Ю. Правовые аспекты международных отношений в Центральной Азии XVIII-XIX вв.: проблемы и перспективы изучения // Центральная Азия 
на перекрестке европейских и азиатских политических интересов: XVIII-XIX вв. М.: ОнтоПринт, 2019. С. 100-108.

ПТР 1960 - Присоединение Туркмении к России (сборник архивных документов) / Акад. наук Туркм. ССР, Ин-т истории, археологии и этнографии АН ТССР, Центр. гос. ист. архив УзССР; под ред. канд. ист. наук А. Ильясова. Ашхабад: Изд-во АН ТССР, $1960.823 \mathrm{c}$.

Ракович 1900 - Ракович Д. В. Тенгинский полк на Кавказе, 1819-1846. Тифлис: Тип. канцелярии главноначальствующего гражданской частью на Кавказе, 1900. 494 с.

Росляков 1955 - Росляков A. А. Аламаны // Coветская этнография. 1955. № 2. С. 41-53.

РТО 1963 - Русско-туркменские отношения в XVIII-XIX вв. (до присоединения Туркмении к России). Сборник архивных документов. Ашхабад: Изд-во АН ТССР, 1963. 784 с.

Салихова 2007 - Салихова Д. Б. Российскоиранские отношения во второй четверти XIX века: автореф. дисс. ... канд. ист. наук. Махачкала, 2007. 28 с.

Сепехр 1390 (2011/2012) - Сепехр Мухаммад

\section{References}

Agaev Kh., Annanepesov M. (comps.) Russian-Turkmen Relations, $18^{\text {th }}-19^{\text {th }}$ Centuries (Prior to Turkmenistan's Incorporation into Russia). Collected archival documents. Ashgabat: Turkmen SSR Academy of Sciences, 1963. 784 p. (In Russ.)

Ali A. D. On military confrontation of Khorezm and Iran in the first half of the XVIII ${ }^{\text {th }}$ century (on the data of written sources). Bulletin of TSU LBP. Series of Humanitarian Sciences. 2018. No. 1 (74). Pp. 40-47. (In Russ.)

Aminov I. I. Turkmens and Russia, $19^{\text {th }}-$ early $20^{\text {th }}$ century: statehood incorporation means revisited. In: Fundamental Science and Technology - Future Developments. Conference proceedings. Vol. 2. Moscow: CreateSpace, 2017. Pp. 169-171. (In Russ.)

Ataev A. T. Turkmens and external policy of the Durrani Empire. Internauka. 2017. No. 8-1 (12). Pp. 27-31. (In Russ.)

Atdaev S. D. The Struggle of Northern Turkmens against Nader Shah Afshar in Khiva. Cand. Sc. (history) thesis abstract. Ashgabat, 1993. 20 p. (In Russ.)

Blaramberg I. F. Memoirs. O. Zhigalina, E. Schmidt (transl.). Moscow: Nauka — GRVL, 1978. 355 p. (In Russ.)

Borovkov A. K. (ed.) Materials in the History of Turkmens and Turkmenistan, $16^{\text {th }}-19^{\text {th }}$ Centu-
Таги Лисан-оль-мольк. Насих ат-тава̄рих. Тарих-е Каджа̄рийе. Т. II. Тегеран: Асатир, 1390 (2011/2012). 352 c.

Хидоятов $1969-$ Хидоятов Г. А. Из истории англо-русских отношений в Средней Азии в конце XIX в. (60-70-х гг.). Ташкент: Фан, $1969.456 \mathrm{c}$.

Широкорад 2013 - Широкорад А. Б. Российские военные базы за рубежом. XVIIIXXI вв. М.: Вече, 2013. 368 с.

Юзефович 1869 - Договоры России с Востоком политические и торговые / сост. Т. Д. Юзефович. СПб.: Тип. О. И. Бакста, 1869. 326 с.

Rawlinson 1875 - Rawlinson Henry. England and Russia in the East. A series of papers on the political and geographical condition of Central Asia. London: J. Murray, 1875. 412 p.

Saray 1989 - Saray Mehmet. The Turkmens in the age of imperialism: A study of the Turkmen people and their incorporation into the Russian Empire. Publication of Turkish Historical Society. Serial: VII - No. 103. Ankara, 1989. 274 p.

Sykes 1921 - Sykes P. M. A History of Persia. Vol. II, London: Macmillan and Co., 1921. $796 \mathrm{p}$.

ries. Vol. 2: Sources from Iran, Bukhara and Khiva. Moscow: USSR Academy of Sciences, 1938. 700 p. (In Russ.)

Deeds Collected by the Caucasus Archaeographic Commission. Vol. 6. Part 2. Tiflis: Caucasus Viceroy's Office, 1875.950 p. (In Russ.)

Deeds Collected by the Caucasus Archaeographic Commission. Vol. 7. Tiflis: Caucasus Viceroy's Office, 1878. 994 p. (In Russ.)

Ikhsanov A. R. The Teke and the Yomut, $18^{\text {th }}-19^{\text {th }}$ centuries: relations between the Turkmen tribes revisited. Vostok (Oriens). 2014. No. 6. Pp. 3242. (In Russ.)

Ilyasov A. (ed.) Turkmenistan's Incorporation into Russia. Collected archival documents. Ashgabat: Turkmen SSR Academy of Sciences, 1960. 823 p. (In Russ.)

Imasheva M. M. Trade of Russia: Via Astrakhan and to the East, Early-to-Mid $19^{\text {th }}$ Century. Cand. Sc. (history) thesis abstract. Astrakhan', 2004. 16 p. (In Russ.)

Ivanov M. S. An Essay in the History of Iran. Moscow: Gospolitizdat, 1952. 467 p. (In Russ.)

Ivanov M. S. Antifeudal Uprisings in Mid- $19^{\text {th }}$ Century Iran. Moscow: Nauka, 1983. 248 p. (In Russ.)

Kadyrov Sh. Kh. The Nation of Tribes: Ethnic Origins, Transformation and Statehood Perspectives in Turkmenistan. Moscow: Institute for African Studies (RAS), 2003. 362 p. (In Russ.) 
Karelin G. S. The Journey of G. Karelin across the Caspian. Ser. 'Transactions of the Imperial Russian Geographical Society: Common Geography'. Vol. 10. St. Petersburg: Imperial Academy of Sciences, 1883. 497 p. (In Russ.)

Khidoyatov G. A. Central Asia, 1860s-1870s: Glimpses of English-Russian Relations. Tashkent: Fan, 1969. 456 p. (In Russ.)

Kuznetsova N. A. Iran in the Early-to-Mid $19^{\text {th }}$ Century. Moscow: Nauka, 1983. 265 p. (In Russ.)

Lobysevich F. I. Systematic Expansion into Central Asia: Trade, Diplomacy, and the Military. St. Petersburg: Obshchestvennaya Polza, 1900. 205 p. (In Russ.)

Nikonov O. A. Development of Interstate Relations in the Asian Caspian, $18^{\text {th }}-19^{\text {th }}$ Centuries. Dr. Sc. (history) thesis abstract. Moscow, 2011. 42 p. (In Russ.)

Nikonov O. N. The Southeastern Caspian in Imperial Russia's political strategy, early-to-mid $19^{\text {th }}$ century. Prepodavatel. XXI vek. 2009. No. 4. Pp. 214-222. (In Russ.)

Ozdamirova E. M. The Turkmen coast of the Caspian Sea in the economic policy of the Tsarist Government in 1800-1820-ies. The Caspian Region: Politics, Economics, Culture. 2015. No. 4 (45). Pp. 59-66. (In Russ.)

Pashuto V. T. Alexander S. Griboyedov and his diplomatic activity. Istoricheskie zapiski. 1947. Vol. 24. Pp. 111-159. (In Russ.)

Pochekaev R. Yu. Imperial Russia's economic sanctions against the Khanate of Khiva, $18^{\text {th }}$ $19^{\text {th }}$ centuries: causes, legal aspects, efficiency. Voprosy pravovedeniya. 2016. No. 3 (37). Pp. 200-215. (In Russ.)

Pochekaev R. Yu. Legal aspects of international relations in Central Asia, $18^{\text {th }}-19^{\text {th }}$ centuries: problems and prospects of research. In: Central Asia as a Crossroads of European and Asian Political Interests, 18th-19th Centuries. Moscow: OntoPrint, 2019. Pp. 100-108. (In Russ.)

Pochekaev R. Yu. State and Law in Central Asia: Eyewitness Accounts of Russian and Western Travelers, $18^{\text {th }}$ to Early $20^{\text {th }}$ Centuries. Moscow: HSE University, 2019. 424 p. (In Russ.)

Popkova O. V. Combat activity as an inherent aspect of the nomadic Turkmen life in the $17^{\text {th }}$ - the first quarter of the $18^{\text {th }}$ century. Scientific Notes of Orel State University. 2016. No. 1 (70). Pp. 46-49. (In Russ.)

Rakovich D. V. Tenginsk Infantry Regiment in the Caucasus, 1819-1846. Tiflis: Chief Caucasus Civil Executive's Office, 1900. 494 p. (In Russ.)
Rawlinson Henry. England and Russia in the East. A series of papers on the political and geographical condition of Central Asia. London: J. Murray, 1875. 412 p. (In Eng.)

Roslyakov A. A. The Alemanni. Sovetskaya etnografiya. 1955. No. 2. Pp. 41-53. (In Russ.)

Salikhova D. B. Russian-Iranian Relations, 1720s-1750s. Cand. Sc. (history) thesis abstract. Makhachkala, 2007. 28 p. (In Russ.)

Saray Mehmet. The Turkmens in the Age of Imperialism: A Study of the Turkmen People and Their Incorporation into the Russian Empire. Publication of Turkish Historical Society. Serial: VII No. 103. Ankara, 1989. 274 p. (In Eng.)

Shirokorad A. B. Overseas Military Bases of Russia, $18^{\text {th }}-21^{\text {st }}$ Centuries. Moscow: Veche, 2013. 368 p. (In Russ.)

Sipihr Muhammad Taqi Lisan al-Mulk. Brief World History. A History of the Qajar Dynasty. Vol. II. Tehran: Asatir, 1390. 352 p. (In Russ.)

Sykes P. M. A History of Persia. Vol. II, London: Macmillan and Co., 1921. 796 p. (In Eng.)

Vasilyev D. V. Russia and Kazakh Steppe: Administrative Policy and Status of the Periphery, $18^{\text {th }}$ to Mid-19 $9^{\text {th }}$ Century. Moscow: Politicheskaya Entsiklopediya, 2014. 471 p. (In Russ.)

Vasilyev D. V. The dualism of the Russian administration on the eastern Caspian coast. Vestnik of Saint Petersburg University. History. 2020. Vol. 65. No. 1. Pp. 85-107. (In Russ.)

Vasilyev D. V., Vasilyev S. D. The British-Russian opposition in the Middle East as the reaction to attempt the strategic strengthening of Russia in the region in 1830s. Izvestiya of Samara Scientific Center of the Russian Academy of Sciences. 2017. Vol. 19. No. 3. Pp. 146-151. (In Russ.)

Vasilyev S. D. British influence on policies of the Shah's Government towards Turkmen tribes: how Iran became a theater of political confrontation between Russia and Great Britain. In: Central Asia as a Crossroads of European and Asian Political Interests, $18^{\text {th }}-19^{\text {th }}$ Centuries. Moscow: OntoPrint, 2019. Pp. 290-300. (In Russ.)

Vasilyev S. D., Vasilyev D. V. Iran at the heart of British-Russian confrontation in the 1820s. Historical, Philosophical, Political and Law Sciences, Culturology and Study of Art. Issues of Theory and Practice. 2017. No. 6-1 (80). Pp. 33-36. (In Russ.)

Yuzefovich T. D. (comp.) Russia's Treaties and Agreements with the East: Political and Trade Ones. St. Petersburg: O. I. Bakst, 1869. 326 p. (In Russ.) 